\title{
Morphological study of anatomical variation of foramen transversarium in cervical vertebrae and its clinical implication
}

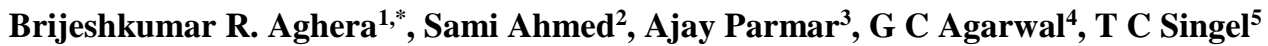 \\ ${ }^{1,3}$ Assistant Professor, ${ }^{2}$ Tutor, ${ }^{4,5}$ Professor, Dept. of Anatomy, Pacific Medical College and Hospital, Udipur, Rajasthan, India
}

*Corresponding Author:

Email: drbrijeshaghera@gmail.com

Received: 21st November, 2017

Accepted: $30^{\text {th }}$ April, 2018

\begin{abstract}
Introduction: The Foramen Transversarium (FT) is a identification feature of cervical vertebrae which differentiate it from the other vertebrae. It is present in the the transverse process of vertebrae. Vertebral artery is pass through this foramen which important for blood supply for brain.

Aim and Objective: To study the anatomical variation in foramen transversarium in cervical vertebrae very important for purpose of diagnostic and surgical important for Surgeon, Radiologist and Neurosurgeon.

Material and Method: In our study, we included 175 dried cervical vertebrae from department of anatomy to detect double foramen FT present in transverse process in cervical vertebrae. Vertebrae with anatomical variation were photographed.

Result: In our study, we found total 24 vertebrae having double FT out of 175 cervical vertebrae. Which include 12 vertebrae having bilateral double FT and 12 vertebrae having unilateral double FT.

Conclusion: Knowledge of this type of anatomical variation in foramen transversarium is important for cervical approach during spine surgery to prevent injury of vascular structures.
\end{abstract}

Keywords: Foramen Transversarium, Vertebral artery, Cervical vertebrae.

\section{Introduction}

The foramen transversarium (FT) is a identification feature of cervical vertebrae which differentiate it from the other vertebrae. It is present in laterally present process called transverse process. Ttransvers process directed laterally and forward, every process contain anterior and posterior root, in between two root foramen transversarium present. Vertebral artery most important artery of the body which supply the brain, at the leval of pons two vertebral artery fused and form basilar artery which supply the brain.vertebral artery have four part in which second part of it pass through upper six foramen transversarium of cervical vertebrae along with it vertebral vein and nerveplexus around it pass, verterbral artery is not pass through seventh cervical forramen transversarium it only contain vertebral vein.

The anatomical variation is occur due to main two cause, if any change in development of vertebral artery or development of coastal element and transvers element if any change in this it cause cerebrovascular insufficiency which is dangerous.

The knowledge of the FT variations are most important for physicians, and radiologist in the diagnosis of the medical conditions. If any abnormal bony growth inside the FT or accessory foramen transversarium which compress the vertebral artery and vertebral vein which cause severe vascular lesion of brain.
Along with it vertebral artery and basilar artery give some branch to inner ear so any lesion in this artery cause the hearing problems.

\section{Materials and Methods}

In our study, 175 dried cervical vertebrae without determine of age and sex from department of anatomy, Pacific Medical University were studied. Then we observed double FT present in laterally placed transverse process in $\mathrm{C} 1$ to $\mathrm{C} 7$ cervical vertebrae. Broken vertebrae were excluded from the study. Vertebrae with this variation were photographed and noted.

\section{Result}

In our study, 24 vertebrae with double FT out of 175 vertebrae. Which include 12 vertebrae having both side double FT and 12 vertebrae having one side double FT. In this typical cervical vertebrae contain double FT were $11.43 \%$ which contain $6.8 \%$ one side double FT and $4.57 \%$ both side FT present and atypical cervical vertebrae contain one side double FT were $2.28 \%$ which contain 2.28 both side double FT. Also two cervical vertebrae (atlas) having a incomplete foramen transversarium. 


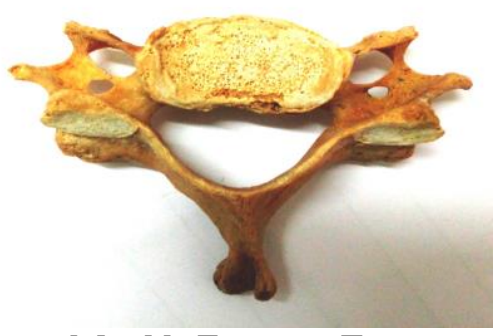

Fig. 1: Bilateral double Foramen Transversarium

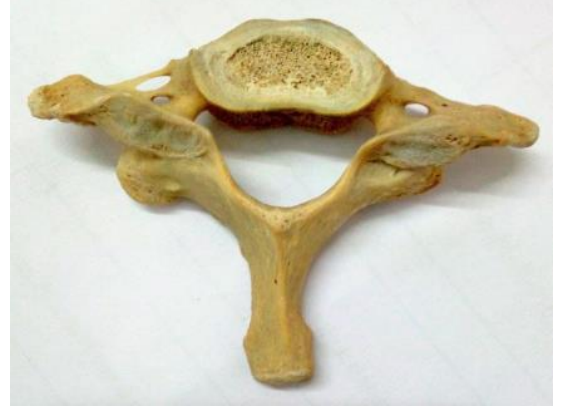

Fig. 2: Unilateral double Foramen Transversarium (left side)

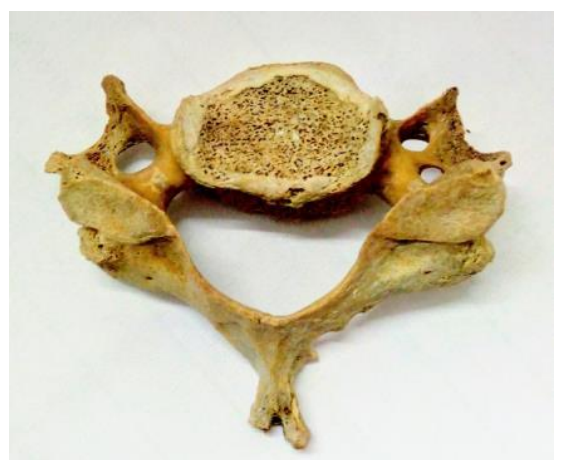

Fig. 3: Unilateral Double Foramen Transversarium (Right side)

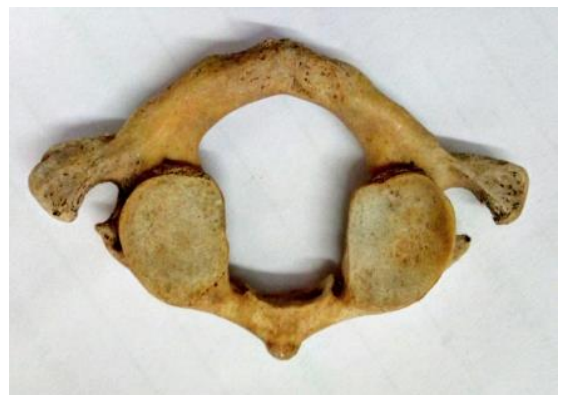

Fig. 4: Incomplete Foramen Transversarium

\section{Discussion}

The cervical vertebrae are identified by presence of foramen transversarium. The foramen transversarium is present between anterior and posterior roots. in cervical vertebrae two element are there one is costal element and other is transvers element, costal element trully present with anterior root, anterior tubercle, costo transeverse bar, Posterior tubercle and lateral part of posterior root,only posterior root represent true transvers element. ${ }^{1,2}$

Developmentally Vertebrae formed by sclerotome part of the somites which derived from paraxial mesoderm. Whole vertebral development is regulated through HOX genes. Costal element meet with true transvers process and form foramen transversarium. ${ }^{3}$

Vertebral artery is a composite artery which develop from various sources. In cervical region intersegmental artery fuse with one other form longitudinal anastomosis in which post costal anastomosis require for development of vertebral artery. Veretebral artery is development from seventh cervical intersegmental artery other intersegmental artery are regress. ${ }^{4}$

In our case first part of the vertebra artery develop from dorsal ramus of the seventh inteasegmenta artery.any alteration in regression of this intersegmental artey which cause duplication of vertebral artery then it alter the fusion of costal element and transvers process which cause duplication of foramen transversarium.

That why it conclude that any alteration in change in the development of first part in vertebral artery cause duplication of foramen transversarium.

In our study we found 24 cervical vertebrae having a double FT. Other study like:

Murlimanju et al studied, total $6(1.6 \%)$ out of 363 vertebra, he found double foramina $5(1.4 \%)$, and both side FT in $1(0.3 \%)$, one sided FT $5(1.4 \%){ }^{5}$

As per Apurva patra et al studied 22\% double FT in which $10.67 \%$ one sided FT and $11.33 \%$ both sided FT out of 150 cervical vertebrae. ${ }^{6}$

According to Chaudhari et al found $23.15 \%$ double FT in which $14.73 \%$ one sided double FT and $8.42 \%$ double sided Double FT out of 133 cervical vertebrae. ${ }^{7}$ According taitz et al Studied he found $7 \%$ double Foramen transversarium. ${ }^{8}$

According to Mishra et al observation he found 14.09 double FT, in which one sided double FT found $4.54 \%$ and $9.54 \%$ both side FT present. ${ }^{9}$

As per Manoj et al reported $14.72 \%$ double FT in which $4.90 \%$ one side double FT and $9.81 \%$ bboth side double FT out of 163 cervical vertebrae. ${ }^{10}$

Various studied like Rathnakaret al, Kaya et al and Katikireddi et al found double FT 5.7\%, 22.72\% and 3 respectively. ${ }^{11-13}$

Other study we noted in table 2 
Table 1: Prevalence of double foramen in cervical vertebrae

\begin{tabular}{|c|c|c|c|}
\hline $\begin{array}{c}\text { Type of } \\
\text { cervicalvertebrae }\end{array}$ & $\begin{array}{c}\text { Incidence of } \\
\text { Double FT\% }\end{array}$ & $\begin{array}{c}\text { Unilateral } \\
\text { Double FT\% }\end{array}$ & $\begin{array}{c}\text { Bilateral } \\
\text { Double FT\% }\end{array}$ \\
\hline Typical cervical vertebrae & 11.43 & 6.8 & 4.57 \\
\hline Atypical cervical vertebrae & 2.28 & 0 & 2.28 \\
\hline
\end{tabular}

Table 2: Various studies on Variation in Foramen Transversarium

\begin{tabular}{|l|c|c|c|c|}
\hline \multicolumn{1}{|c|}{ Authors } & $\begin{array}{c}\text { Number of } \\
\text { vertebrae studied }\end{array}$ & $\begin{array}{c}\text { Percentage } \\
\text { of Double FT }\end{array}$ & $\begin{array}{c}\text { One sided } \\
\text { Double FT\% }\end{array}$ & $\begin{array}{c}\text { Both sided } \\
\text { Double FT \% }\end{array}$ \\
\hline Vivek singh $^{14}$ & 420 & 13.81 & 8.81 & 5 \\
\hline Apurba Patra & 150 & 22 & 10.67 & 11.33 \\
\hline Ridhdhish $^{15}$ & 865 & 9.02 & 4.4 & 4.62 \\
\hline Chandravadiya $^{16}$ & 140 & 4.76 & 3.8 & 0.95 \\
\hline Jawed akhter $^{17}$ & 174 & 14.36 & 11.49 & 2.87 \\
\hline Sharma & 18 & 8 & 3.5 & 4.5 \\
\hline Present study & 200 & 13.7 & 6.8 & 6.77 \\
\hline
\end{tabular}

\section{Conclusion}

Vertebral Artery vascular insufficiency occur due to any alter any path of artery or duplication of foramen transversarium. Our study and other studies suggest that knowledge of this type of anatomical variation is useful for diagnostic and surgical important for radiologist and spine surgeon.

Abbreviation: FT- Foramen Transversarium.

\section{References}

1. Standring S, 40th ed. Gray's anatomy-The anatomical Basis of Clinical Practice. Spain: Churchill Livingstone Elsevier.

2. (2005):718-21

3. A K Dutta Essential of Human Osteology $2^{\text {nd }}$ edition (2005):32-3.

4. Murlimanju, B. V.; Prabhu, L. V. Shilpa, K.; Rai, R.; Dhananjaya, K. V. \& Jiji, P. J. Accessory transverse foramina in the cervical spine: Incidence, embryological basis, morphology and surgical importance. Turk. Neurosurg.(2011);21(3):384-7.

5. A K Dutta, Essential of Human Embryology, $6^{\text {th }}$ edition (2010):182-3

6. Murlimanju, B. V.; Prabhu, L. V. Shilpa, K.; Rai, R.; Dhananjaya, K. V. \& Jiji, P. J. Accessory transverse foramina in the cervical spine: Incidence, embryological basis, morphology and surgical importance. Turk. Neurosurg.(2011);21(3):384-7.

7. Patra A, Kaur H, Chhabra U, Kaushal S, Kumar U. Double foramen transversarium in dried cervical vertebra: An osteological study with its clinical implications. Indian J Oral Sci (2015);6:7-9.

8. Chaudhari ML, Maheria PB, Bachuwar SP. Double foramen transversarium in cervical vertebra: Morphology and clinical importance.Indian J Basic Appl Med Res (2013);2:1084-8.

9. Taitz C, Nathan H, Arensburg B. Anatomical observations of the foramina transversaria. J Neurol Neurosurg Psychiatry. (1978);41:170-6.

10. Mishra G P, Bhatnagar S, Singh B, Mishra P P, Mishra A. Anatomical Variations in Foramen Transversarium of
Typical Cervical Vertebrae and Clinical Significance. IJBR. (2014);5(6):405-7.

11. Manoj P Ambali, Surekha D Jadhav. Anatomical variation in foramen transversarium of Typicacal cervicacl vertebrae and its clinical significance. Int $\mathbf{J}$ Anat Res (2017);5(1):3426-9.

12. Rathnakar P, Remya K, Swathi B. Study of accessory foramen transversaria in cervical vertebrae. Nitte Univ $\mathbf{J}$ Health Sci (2013);3:97-9.

13. Kaya, S.; Yilmaz, N. D.; Pusat, S.; Kural, C.; Kirik, A. \& Izci, Y. Double foramen transversarium variation in ancient Byzantine cervical vertebrae: Preliminary report of an anthropological study. Turk. Neurosurg (2011);21(4):534-8.

14. Katikireddi RS, Setty SN. A study of double foramen transversarium in dried cervical vertebra. Int J Health Sci Res (2014);4:59-61.

15. Vivek Singh Malik, Gargi Soni, Vipin Garsa, SK Rathee, Sanjay Gupta.An osteological study of double foramina transversarium of cervical vertebrae. Int J Anat Res 2017;5(1):3527-9.

16. Ridhdhish et al.double foramina transversarium of cervical vertebrae,morphological study International Journal of Anatomy and Physiology (2015);4 (6):089-92.

17. Chandravadiya L, Patel S, Goda J, Chavda V, Ruparelia S, Patel S. Double foramen transversarium in cervical vertebra: Morphology and clinical importance. Int J Res Med (2013);2:103-5.

18. Akhtar MJ, Madhukar PK, Rahman S, Kashyap N. A morphometric study of foramen transversarium of dried cervical vertebrae. Int J Res Med Sci (2015);3:912-6.

19. Sharma A, Singh K, Gupta V et al. Double foramen transversarium in cervical vertebra an osteological study. J Anat Soc India. (2010);59(2):229-31. 